\title{
Procesy kształtowania się przemysłu komputerowego Brazylii
}

Brazylia posiada najlepiej rozwinięty przemysł zaawansowanych technologii i sektor informatyczny (IT) spośród wszystkich państw Ameryki Łacińskiej. Jest to w dużej mierze zasługą realizowanych od lat 70. XX w. programów rozwoju rodzimego sektora wysokich technologii, które miały doprowadzić do zredukowania zapóźnienia technologicznego kraju. Kolejne rządy starały się prowadzić politykę ograniczania zależności od importowanych technologii, szczególnie w dynamicznie rozwijającym się na świecie przemyśle komputerowym. Władze Brazylii świadome wielkości krajowego rynku zbytu na tego typu produkty oraz strategicznego znaczenia rozwoju nowoczesnych gałęzi przemysłu zdecydowały się na realizację silnie protekcjonistycznej polityki, zmierzającej do wykreowania krajowych producentów komputerów i oprogramowania, a następnie zapewnienia im sprzyjających warunków do rozwoju i konkurencji z międzynarodowymi firmami z tego sektora.

Protekcjonistyczna polityka władz przyczyniła się do powstania dużego sektora informatycznego, w którym na początku lat 80 . XX w. dominowały brazylijskie firmy. Od połowy lat 80 nasiliły się naciski Stanów Zjednoczonych, mające na celu doprowadzenie do szerszego otwarcia brazylijskiego rynku dla amerykańskich firm komputerowych. Odpowiedzią na nie była częściowa liberalizacja wymiany handlowej i stopniowe otwieranie brazylijskiego rynku dla zagranicznych firm. Diametralna zmiana polityki w sektorze informatycznym nastąpiła na początku lat 90., wraz z przyjęciem w 1991 r. ustawy nr 8248/91, która kończyła z dotychczasową strategią ochrony krajowych producentów na rzecz polityki promocji i zachęt do rozwoju produkcji w Brazylii. Ustawa zmierzała do ustanowienia alternatywnych mechanizmów ochrony krajowej produkcji oraz badań poprzez różnego rodzaju redukcje podatków i opłat, w przypadku gdy firmy zdecydują się na pewien poziom lokalnej produkcji, udział miejscowych podzespołów oraz określone wydatki na B\&R. Zniesiono natomiast bariery importowe i ograniczenia dla zagranicznych inwestorów. Zmiana polityki w tym zakresie doprowadziła do dużego napływu zagranicznych inwestycji koncernów międzynarodowych, które starały się wkroczyć na ten rynek zarówno poprzez inwestycje greenfield, jak i poprzez przejęcie istniejących firm brazylijskich. Konsekwencją wprowadzonej na początku lat 90 . liberalizacji polityki w sektorze informatycznym było zdominowanie go przez duże międzynarodowe korporacje, co z kolei zepchnęło krajowe firmy do wyspecjalizowanych nisz produkcyjnych.

Celem artykułu jest przedstawienie historii rozwoju przemysłu komputerowego w Brazylii ze szczególnym uwzględnieniem uwarunkowań instytucjonalno-prawnych wpływających na jego rozwój. Uwaga została zwrócona przede wszystkim na przekształ- 
cenia dokonujące się w tym sektorze po 1991 r. Największy nacisk położono na analizę zmian w przestrzennym rozmieszczeniu zakładów przemysłu komputerowego w Brazylii w latach 1995-2006.

\section{RozWÓJ PRZEMYSŁU KOMPUTEROWEGO BRAZYLII PO II WOJNIE ŚWIATOWEJ}

Początki brazylijskiego przemysłu komputerowego wiążą się z prężnie działającą w tym kraju grupą fizyków, którzy zwrócili uwagę na znaczenie gospodarcze oraz militarne rodzącego się przemysłu komputerowego. Odegrali oni też decydującą rolę w konstruowaniu pierwszych brazylijskich komputerów w latach 60. i 70. XX w. Szczególne znaczenie w tym zakresie odegrali naukowcy zajmujący się fizyką jądrową oraz fizyką ciała stałego. Starali się także wywierać naciski i zwracać uwagę rządzących na konieczność rozwoju tego sektora gospodarki (Langer 1989, Adler, 1986, Erber 1985).

Pierwsze działania zmierzające do rozwinięcia krajowego przemysłu komputerowego podjął w 1959 r. prezydent Juscelinio Kubitschek, powołując tzw. Grupę Wykonawczą do spraw Wykorzystania Komputerów (Grupo Executivo para Aplicação de Computadores Electrônicos - GEACE). Utworzenie tej agencji wskazywało na poważne zainteresowanie władz rozwojem przemysłu nowych technologii. Główne wsparcie instytucjonalne dla powstałej agencji miała zapewnić brazylijska marynarka wojenna, która także wykazywała największe zainteresowanie w rozwoju nowoczesnych technologii i ich wykorzystaniu dla celów militarnych. Działania GEACE w latach 60. XX w. były ograniczone w związku z napiętą sytuacją polityczną, która doprowadziła do przewrotu wojskowego w $1964 \mathrm{r}$. Zostały jednak stworzone podstawy do dalszego rozwoju badań w tym zakresie, a także wzrosła świadomość konieczności rozwoju tego sektora gospodarki wśród szerszego grona osób z kręgów politycznych, militarnych i biznesowych (Langer 1989, s. 97-98).

Kolejny etap rozwoju przemysłu komputerowego rozpoczyna się z początkiem lat 70. XX w. Wiąże się on z gwałtownym boomem gospodarczym, jaki przeżywała Brazylia w latach 1968-1973. Wraz z dynamicznym rozwojem gwałtownie wzrastało zapotrzebowanie na komputery na rynku krajowym. Rządzący technokraci coraz wyraźniej dostrzegali także konieczność wspierania tego sektora przemysłu, obserwując politykę prowadzoną przez państwa wysokorozwinięte. W tym celu w kwietniu 1972 r. powołano Komisję ds. Koordynacji Działań Związanych z Elektronicznym Przetwarzaniem Danych (Comissão de Coordenação das Atividades de Processamento Eletrônico CAPRE), organ rządowy podporządkowany Ministerstwu Planowania, którego celem było promowanie wykorzystania komputerów i prowadzenie polityki wspierającej rozwój technologicznego w sektorze informatycznym. W 1975 r. CAPRE uzyskała szerokie uprawnienia nadzoru i autoryzacji całego brazylijskiego importu komputerów, części i akcesoriów. Podniesiono cła importowe, wymagano wpłaty nieoprocentowanych zaliczek na poczet importu wyrobów przemysłu komputerowego oraz wprowadzono limity importowe (Adler 1986, s. 692-695).

Prowadzona polityka zmierzała do ograniczenia importu i skłonienia koncernów międzynarodowych do inwestycji w Brazylii. Starano się także promować krajowych producentów w tym sektorze. W związku z niedostatkiem prywatnych kapitałów krajowych potrzebnych w rozwoju tego typu działalności przemysłowej zakładano firmy państwowe. Najbardziej znaną z nich jest powstała w 1974 r. COBRA (Computadores e Sistemas 
Brasileiros Ltd.) - pierwsze brazylijskie przedsiębiorstwo państwowe produkujące komputery na rynek krajowy (Adler 1986, Evans 1986, Erber 1985).

W grudniu 1979 r. CAPRE zostało zastapione przez Specjalny Sekretariat ds. Informatyki (Secretaria Especial de Informática - SEI) związany z Narodową Radą Bezpieczeństwa i składający sprawozdania bezpośrednio prezydentowi kraju. Celem powstałego sekretariatu było opracowanie i wprowadzenie w życie Narodowej Polityki Rozwoju Informatyki (Política Nacional de Informática). Jednym z głównych zadań SEI było kontynuowanie wprowadzonej w 1977 r. ,,polityki rezerwy rynku” (market reserve policy), która zmierzała do ochrony i zarezerwowania wybranych segmentów wewnętrznego rynku dla krajowych przedsiębiorstw sektora komputerowego. Od początku lat 80. XX w. urzędnicy SEI zmagali się $\mathrm{z}$ dwoma przeciwstawnymi tendencjami. $\mathrm{Z}$ jednej strony narastały naciski zmierzające do większego otwarcia Brazylii na inwestycje korporacji międzynarodowych w sektorze informatycznym, z drugiej zaś stowarzyszenia skupiające producentów komputerów, sprzętu peryferyjnego oraz usług IT starały się wymusić dalsze rozszerzenie ,polityki rezerwy rynku" (Adler 1986, Evans 1986, Amann, Baer 2002).

W drugiej połowie lat $80 . \mathrm{XX}$ w. protekcjonistyczna polityka SEI ulegała stopniowemu rozmyciu w miarę rosnącego uzależnienia i powiązania technologicznego, a także kapitałowego brazylijskich przedsiębiorstw z korporacjami międzynarodowymi. Dodatkowym czynnikiem zmuszającym SEI do złagodzenia restrykcyjnej polityki importowej było rozpoczęcie w 1985 r. przez Stany Zjednoczone dochodzenia przeciwko brazylijskiemu prawu ograniczającemu eksport amerykańskich firm komputerowych i wypierającemu je z brazylijskiego rynku. Obawy przed utratą dostępu do amerykańskiego rynku zbytu i nałożeniem kar skłoniły Brazylię do stopniowej liberalizacji protekcjonistycznej polityki przemysłowej i importowej (szerzej patrz: Evans 1989, Schoonmaker 1995).Nowy etap w rozwoju brazylijskiego przemysłu komputerowego wyznacza przyjęta w $1991 \mathrm{r}$. ustawa liberalizująca protekcyjną politykę przemysłową i wystawiająca krajowych producentów na międzynarodową konkurencję. Ustawa 8.248/91 zmierzała do wprowadzenia alternatywnych mechanizmów zachęcających firmy z sektora IT do rozwoju krajowej produkcji oraz zwiększania nakładów na B\&R poprzez różnego rodzaju bodźce fiskalne, polegające na redukcji podatku dochodowego, odstąpieniu od podatku od dóbr przemysłowych (industrialized goods tax), których wielkość była uzależniona od wielkości inwestycji w produkcję czy B\&R. Nowa polityka doprowadziła w krótkim okresie do stopniowego przejęcia większości krajowych firm przez duże koncerny międzynarodowe. Wiązało się to z odejściem od lokalnego projektowania i produkowania na rzecz importu gotowych wyrobów bądź półproduktów i ograniczenia się do prostego montażu. Krajowe przedsiębiorstwa, którym udało się przetrwać liberalizację rynku na początku lat 90., zajęły się produkcją niszowych wyrobów oraz nastawiły na obsługę lokalnych klientów, szczególnie w sektorze oprogramowania komputerowego i sprzętu telekomunikacyjnego. Przykładami takich firm są: Itautec, Procomp i SID wyspecjalizowane w automatyzacji i komputeryzacji sektora bankowego (Dedrick i in. 2001, Tigre, Botelho 2001).

\section{ZMIANY W BRAZYLIJSKIM PRZEMYŚLE KOMPUTEROWYM}

Analiza zmian, jakie zaszły w latach 1994-2006 w brazylijskim przemyśle komputerowym, ogranicza się do prześledzenia ogólnych tendencji w liczbie zakładów oraz wielkości zatrudnienia, a także ich regionalnym rozmieszczeniu w układzie stanowym. Zwrócono 
także uwagę na zmianę udziału przemysłu komputerowego (hardware) w ogólnych dochodach sektora informatycznego, jak również prześledzono zmiany w wielkości produkcji wybranych wyrobów w latach 2001-2006. Za przemysł komputerowy uznano grupę 30.2 w brazylijskiej Narodowej Klasyfikacji Aktywności Gospodarczej (Classificação Nacional de Atividades Econômicas - CNAE), w której skład wchodzą dwie klasy działalności przemysłowej (tab. 1). Wykorzystane dane pochodzą z kolejnych roczników Pesquisa Industrial, wydawanych przez brazylijski urząd statystyczny.

Tab. 1. Przemysł komputerowy

w brazylijskiej Narodowej Klasyfikacji Aktywności Gospodarczej (CNAE)

\begin{tabular}{|l|l|}
\hline $\begin{array}{l}\text { Seção D } \\
\text { Sekcja D }\end{array}$ & $\begin{array}{l}\text { Industrias de transformação } \\
\text { Przemysł przetwórczy }\end{array}$ \\
\hline $\begin{array}{l}\text { Divisão } 30 \\
\text { Dzial 30 }\end{array}$ & $\begin{array}{l}\text { Fabricação de maquinas para escritorio e equipamnetos de informatica } \\
\text { Produkcja maszyn biurowych i sprzętu informatycznego }\end{array}$ \\
\hline Grupo 30.2 & $\begin{array}{l}\text { Fabricação de maquinas e equipamentos de sistemas eletronicos para } \\
\text { processamento do dados } \\
\text { Produkcja maszyn i sprzętu elektronicznego do przetwarzania danych }\end{array}$ \\
\hline $\begin{array}{l}\text { Grupa 30.2 } 30.21-0 \\
\text { Klasa 30.21-0 }\end{array}$ & $\begin{array}{l}\text { Fabricação de computadores } \\
\text { Produkcja komputerów } \\
\text { Fabricação de equipamentos periféricos para máquinas eletrônicas } \\
\text { para tratamento de informaçőes } \\
\text { Produkcja urządzeń peryferyjnych do maszyn elektronicznych } \\
\text { do obróbki danych }\end{array}$ \\
\hline
\end{tabular}

Źródło: opracowanie własne na podstawie: Pesquisa Industrial-Empresa 2006

Wielkość zatrudnienia w przemyśle komputerowym w badanym okresie wzrosła ponad 3,5-krotnie z 10,5 tys. do 37,4 tys. osób. Liczba zakładów przemysłu komputerowego również wykazywała tendencję wzrostową w latach 1994-2002, kiedy zwiększyła się ona o ok. 34,5\%. Natomiast w latach 2003-2006 odnotowano zmniejszenie się ich liczby, wynikające z postępujących procesów koncentracji działalności, które doprowadziły do upadku mniejsze i słabsze firmy bądź ich przejęcia przez większych konkurentów. Przyczyniło się to do podniesienia wskaźnika średniej wielkości zatrudnienia w zakładach przemysłu komputerowego z ok. 26-30 osób w latach 90. XX w. do 86 osób w 2006 r. (ryc. 1).

Rozwój zatrudnienia w przemyśle komputerowym nawiązuje do generalnych tendencji rozwojowych sektora informatycznego Brazylii. W badanym okresie można wydzielić trzy główne fazy. Pierwsza obejmuje lata 1993-2000 i cechuje się stopniowym wzrostem dochodów brutto w segmencie hardware, któremu towarzyszył także wzrost zatrudnienia w przemyśle komputerowym. Kolejna faza, obejmująca lata 2001-2004, cechuje się gwałtownym spadkiem dochodów w segmencie hardware i całym sektorze informatycznym, któremu towarzyszyło także krótkotrwałe zmniejszenie zatrudnienia w przemyśle komputerowym (szczególnie w latach 2001-2002). Faza ta wiąże się z kryzysem gospodarczym, który objął Argentynę, ważnego partnera handlowego Brazylii, a następnie przeniósł się na brazylijską gospodarkę (ryc. 2). 


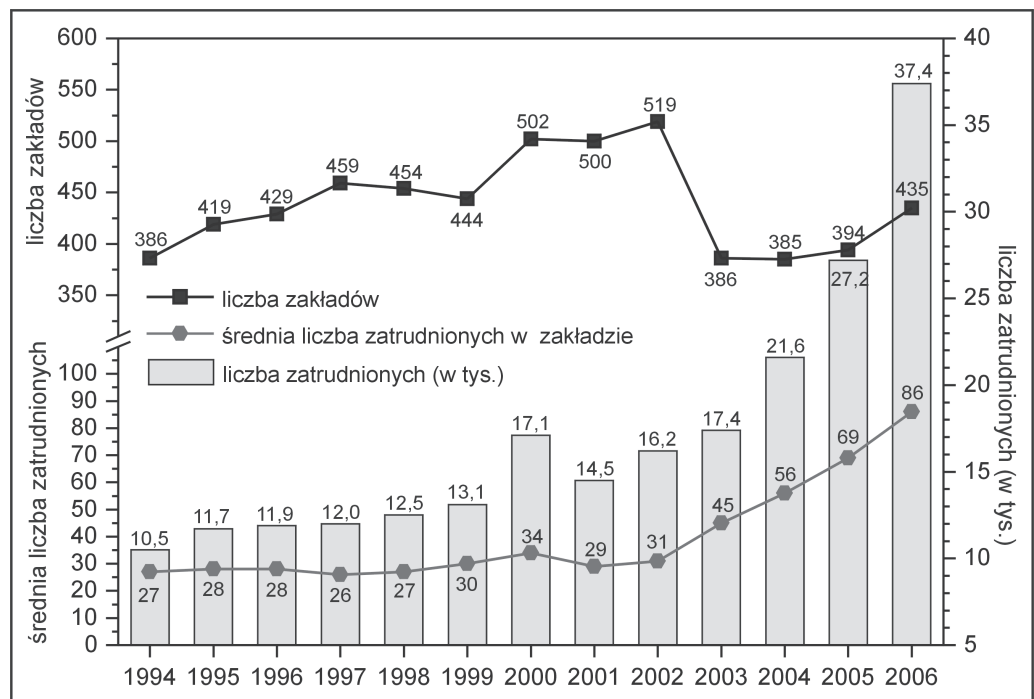

Ryc. 1. Zmiany liczby zakładów oraz wielkości zatrudnienia w przemyśle komputerowym Brazylii w latach 1994-2006

Źródło: opracowanie własne na podstawie: Pesquisa Industrial-Empresa 1994-2006

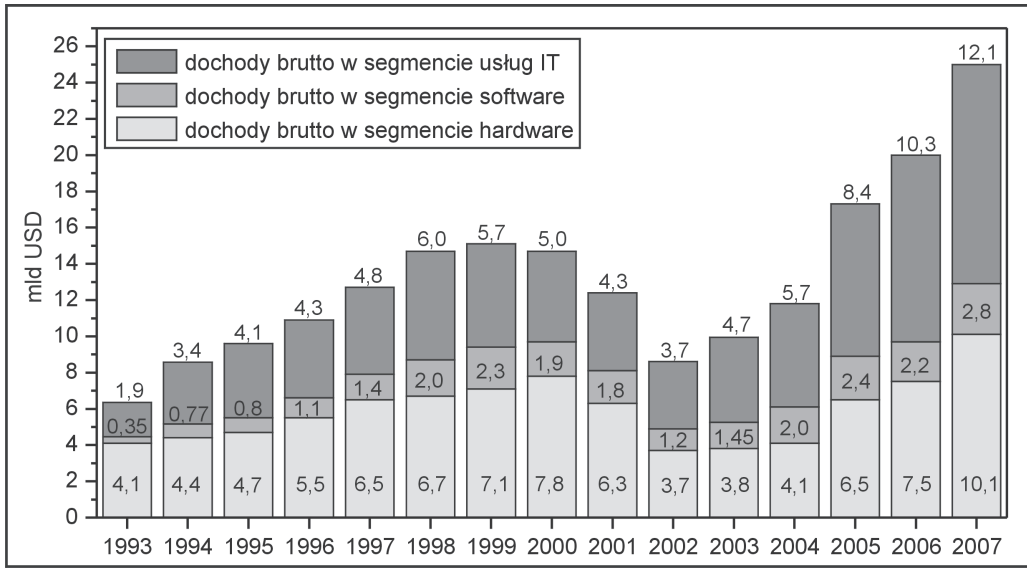

Ryc. 2. Zmiany wielkości dochodów według segmentów sektora informatycznego Brazylii w latach 1993-2007

Źródło: opracowanie własne na podstawie: Anuario Informatica Hoje 2008

Ostatnia faza obejmuje lata 2005-2007 i cechuje się dynamicznym wzrostem dochodów w segmencie hardware, a także szerzej w całym sektorze informatycznym. Towarzyszył temu dynamiczny wzrost zatrudnienia w przemyśle komputerowym (ryc. 1) oraz wzrost produkcji i sprzedaży głównych jego wyrobów (ryc. 3). Wiązało się to z ożywieniem gospodarczym oraz dużymi programami rządowymi zmierzającymi do komputeryzacji administracji państwowej oraz zwiększenia dostępu do komputerów w szkołach i wśród najuboższych grup 
społecznych. W 2003 r. w ramach szerszego Programu Włączenia Cyfrowego (Programa de Inclusão Digital) realizowanego przez Ministerstwo Nauki i Technologii, zainicjowano program Komputer dla Wszystkich (Computador para Todos), co znacząco zwiększyło zakupy sprzętu i oprogramowania komputerowego, zwłaszcza od 2005 r.

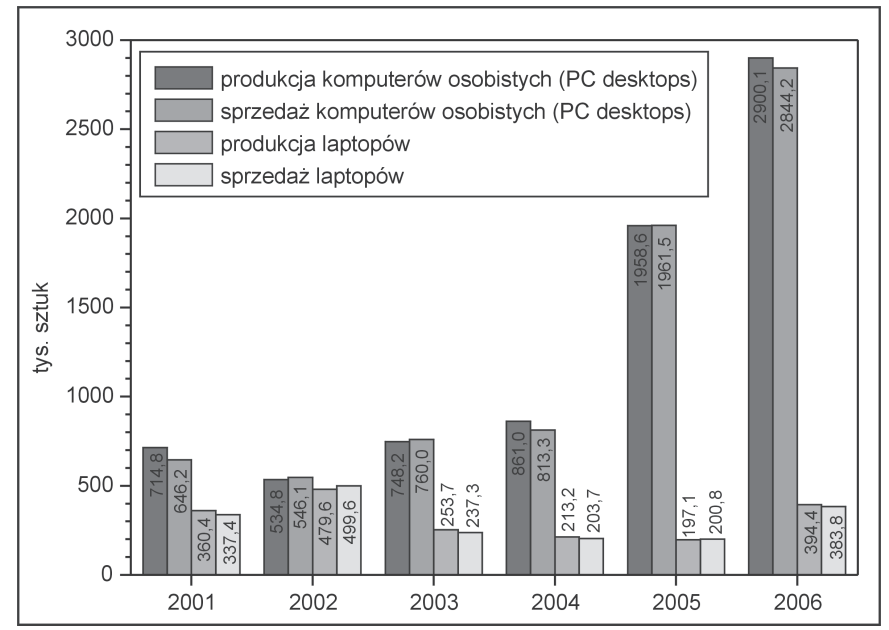

Ryc. 3. Zmiany wielkości produkcji oraz sprzedaży komputerów i laptopów w latach 2001-2006

Źródło: opracowanie własne na podstawie Pesquisa Industrial-Produto 2001-2006

\section{ZMIANY W REGIONALNYM ROZMIESZCZENIU}

\section{BRAZYLIJSKIEGO PRZEMYSŁU KOMPUTEROWEGO W LATACH 1995-2006}

Przemysł komputerowy wykazuje silną tendencję do koncentracji przestrzennej, która związana jest głównie z przestrzennym zróżnicowaniem poziomu rozwoju gospodarczego poszczególnych stanów Brazylii. Dominującą pozycję w koncentracji działalności przemysłu komputerowego zajmuje stan São Paulo, w którym w 1994 r. zlokalizowanych było ponad 50,6\% wszystkich zakładów i aż $62 \%$ ogółu zatrudnionych w tym sektorze. W ostatnich latach wyraźnie zaznacza się jednak stopniowy spadek znaczenia tego stanu, w miarę postępującego procesu dekoncentracji przemysłu komputerowego, co jest związane z nowymi inwestycjami lokalizowanymi w innych częściach Brazylii w ramach programów tworzenia parków i inkubatorów technologicznych (Almeida 2005, Etzkowitz i in. 2005). W 2006 w stanie São Paulo zlokalizowanych było już tylko ok. 42\% ogółu zakładów i 43\% całkowitego zatrudnienia w przemyśle komputerowym (tab. 2). Głównym obszarem koncentracji przemysłu komputerowego w stanie São Paulo jest Region Metropolitalny Campinas, nazywany też brazylijską Silicon Valley ze względu na dużą koncentrację firm z sektora IT, które zlokalizowały się w tym mieście lub jego najbliższym sąsiedztwie. Najważniejsze z nich to: IBM, Lucent, Samsung, Nortel, Compaq, Motorola, Dell, Fairchild, Huawei, 3M, Texas Instruments, Celestica, Solectron oraz Bosch (Quandt 1997). Poza tym istotną rolę w koncentracji zakładów przemysłu komputerowego w tym stanie odgrywają także takie ośrodki jak São Paulo czy São Carlos (Science, Technology \& Innovation Indicators... 2005). 
Tab. 2. Rozmieszczenie zatrudnionych i zakładów przemysłu komputerowego w Brazylii w 1995 i 2006

\begin{tabular}{|c|c|c|c|c|c|c|c|c|}
\hline \multirow{3}{*}{ Stany } & \multicolumn{4}{|c|}{ Liczba zakładów } & \multicolumn{4}{|c|}{ Liczba zatrudnionych } \\
\hline & \multicolumn{2}{|c|}{1995} & \multicolumn{2}{|c|}{2006} & \multicolumn{2}{|c|}{1995} & \multicolumn{2}{|c|}{2006} \\
\hline & liczba & $\mathrm{w} \%$ & liczba & w \% & liczba & w \% & liczba & w \% \\
\hline Acre & - & - & - & - & - & - & - & - \\
\hline Alagoas & 1 & 0,2 & 2 & 0,5 & 3 & 0,0 & - & - \\
\hline Amapa & - & - & 1 & 0,2 & - & - & - & - \\
\hline Amazonas & 23 & 5,5 & 25 & 5,7 & 717 & 6,1 & 5840 & 15,6 \\
\hline Bahia & 6 & 1,4 & 49 & 11,3 & 128 & 1,1 & 1855 & 5,0 \\
\hline Ceara & 6 & 1,4 & 7 & 1,6 & 152 & 1,3 & 250 & 0,7 \\
\hline Dystrykt Federalny & 10 & 2,4 & 8 & 1,8 & 160 & 1,4 & 328 & 0,9 \\
\hline Espirito Santo & 4 & 1,0 & 4 & 0,9 & 165 & 1,4 & 83 & 0,2 \\
\hline Goias & 2 & 0,5 & 6 & 1,4 & 17 & 0,1 & 177 & 0,5 \\
\hline Maranhao & 1 & 0,2 & 2 & 0,5 & 5 & 0,0 & - & - \\
\hline Mato Grosso & 1 & 0,2 & 3 & 0,7 & 5 & 0,0 & 47 & 0,1 \\
\hline Mato Grosso do Sul & 2 & 0,5 & 2 & 0,5 & 11 & 0,1 & - & - \\
\hline Minas Gerais & 31 & 7,4 & 43 & 9,9 & 551 & 4,7 & 4000 & 10,7 \\
\hline Para & 3 & 0,7 & 2 & 0,5 & 29 & 0,2 & - & - \\
\hline Paraiba & - & - & 3 & 0,7 & - & - & 55 & 0,1 \\
\hline Parana & 22 & 5,3 & 17 & 3,9 & 210 & 1,8 & 3628 & 9,7 \\
\hline Pernambuco & 5 & 1,2 & 4 & 0,9 & 66 & 0,6 & 144 & 0,4 \\
\hline Piaui & 1 & 0,2 & 2 & 0,5 & 4 & 0,0 & - & - \\
\hline Rio de Janeiro & 42 & 10,0 & 19 & 4,4 & 906 & 7,7 & 2425 & 6,5 \\
\hline Rio Grande do Norte & 1 & 0,2 & 4 & 0,9 & 4 & 0,0 & 52 & 0,1 \\
\hline Rio Grande do Sul & 29 & 6,9 & 29 & 6,7 & 1190 & 10,2 & 1940 & 5,2 \\
\hline Rondonia & 2 & 0,5 & 1 & 0,2 & 8 & 0,1 & - & - \\
\hline Roraima & - & - & 1 & 0,2 & - & - & - & - \\
\hline Santa Catarina & 14 & 3,3 & 15 & 3,4 & 110 & 0,9 & 319 & 0,9 \\
\hline São Paulo & 212 & 50,6 & 181 & 41,6 & 7263 & 62,0 & 16214 & 43,3 \\
\hline Sergipe & 1 & 0,2 & 3 & 0,7 & 3 & 0,0 & 70 & 0,2 \\
\hline Tocantins & - & - & 2 & 0,5 & - & - & - & - \\
\hline Ogółem & 419 & 100,0 & 435 & 100,0 & 11707 & 100,0 & 37427 & 100,0 \\
\hline
\end{tabular}

Źródło: opracowanie własne na podstawie: Pesquisa Industrial-Empresa 1995-2006

Dynamicznie rozwija się także przemysł komputerowy w stanie Amazonas, co jest związane z utworzeniem strefy bezcłowej w sąsiedztwie stolicy stanu Manaus, w której preferowano inwestycje przemysłu elektronicznego, telekomunikacyjnego i komputerowego. Taka polityka sprawiła, iż miasto to stało się ważnym centrum nowoczesnego przemysłu, w którym swoje zakłady produkcyjne zlokalizowały takie firmy, jak Nokia, Sagem, Gradiente, 
BenQ-Siemens, Samsung, Sony, LG, Itautec oraz SEMP-Toshiba. W 2006 r. stan Amazonas był na drugim miejscu pod względem koncentracji zatrudnienia $\mathrm{w}$ przemyśle komputerowym - skupiał 15,6\% ogółu zatrudnionych (tab. 2).

Ważną pozycję w regionalnym rozmieszczeniu przemysłu komputerowego Brazylii zajmują także stany Minas Gerais oraz Parana, skupiające odpowiednio 10,7\% i 9,7\% ogółu zatrudnionych w tym sektorze w skali kraju. W przypadku Minas Gerais najważniejszymi ośrodkami przemysłu komputerowego są Belo Horizonte i Santa Rita do Sapucai, natomiast w Paranie Kurytyba i Londrina. Na dalszych pozycjach pod względem koncentracji zatrudnienia w przemyśle komputerowym znajdują się stany Rio de Janeiro, Rio Grande do Sul i Bahia, skupiające odpowiednio 6,5\%, 5,2\% i 5,0\% ogółu zatrudnionych w tym sektorze w skali kraju (tab. 2).

\section{Podsumowanie}

W rozwoju brazylijskiego przemysłu komputerowego należy wyróżnić kilka okresów związanych ze zmianami prowadzonej polityki gospodarczej państwa. Pierwszy z nich obejmuje lata 1959-1972 - poczyniono w nim pierwsze kroki w celu oceny zastosowania komputerów w różnych sektorach gospodarki, określenia ich znaczenia w dalszym rozwoju gospodarczym oraz oceny możliwości rozwoju rodzimego przemysłu komputerowego. W okresie tym uświadomiono sobie znaczenie tego przemysłu dla rozwoju gospodarczego oraz technologicznego państwa. Ukształtowały się wówczas grupy naukowców, technokratów i polityków promujące jego rozwój.

Drugi okres obejmuje lata 1972-1991 i charakteryzuje się rozwojem rodzimego przemysłu komputerowego objętego protekcjonistyczną ochroną państwa przed konkurencją międzynarodowych firm. Taka polityka była zgodna z realizowaną od lat 30. XX w. ogólną strategią industrializacji poprzez substytucję importu. W przeciwieństwie do innych sektorów przemysłu, w których starano się przyciągnąć zagranicznych inwestorów i zachęcić ich do rozwoju produkcji w Brazylii bądź nawiązania współpracy join venture z krajowymi firmami, w przemyśle komputerowym od początku starano się ograniczyć aktywność korporacji międzynarodowych, aby umożliwić jak najlepszy rozwój rodzimych przedsiębiorstw. Elity polityczne i wojskowe odpowiedzialne za politykę gospodarczą i militarną kraju zdawały sobie sprawę ze strategicznego znaczenia tego przemysłu, dlatego za wszelką cenę dążono do wykreowania narodowego przemysłu komputerowego będącego w stanie konkurować na arenie międzynarodowej. O determinacji rządzących świadczy aktywna rola państwa $\mathrm{w}$ tworzeniu przedsiębiorstw przemysłowych działających w tym sektorze. Z powodu niedoboru prywatnych kapitałów krajowych przedsiębiorców państwo zaczęło aktywnie działać na rzecz zintensyfikowania badań w tym sektorze i wdrażania ich wyników do seryjnej produkcji. Ochrona rodzącego się krajowego rynku urządzeń przemysłu komputerowego zmierzała do wykluczenia konkurencji międzynarodowych firm z tych jego obszarów, na których popyt na produkty były w stanie zaspokoić rodzime przedsiębiorstwa. Taką politykę zaczęto aktywnie stosować od 1977 r., określając ją mianem ,polityki rezerwy rynku” (market reserve policy) i rozszerzając, w miarę rozwoju krajowego przemysłu, na powiększający się segment wyrobów przemysłu komputerowego.

Rosnące utrudnienia w dostępie do rozwijającego się brazylijskiego rynku komputerowego były coraz ostrzej krytykowane przez międzynarodowe korporacje, które starały się wywierać naciski na władze w celu liberalizacji polityki. Koncerny amerykańskie zaczęły 
też naciskać na rząd Stanów Zjednoczonych, co skłoniło w 1985 r. prezydenta R. Reagana do wszczęcia procedury ukarania Brazylii za zbyt protekcyjną politykę $\mathrm{w}$ tym sektorze. Prowadzone przez następna lata negocjacje dwustronne zmusiły Brazylię do stopniowej liberalizacji prowadzonej polityki. Pod koniec lat 80 . XX w. coraz wyraźniej było widać, iż nadmierny protekcjonizm doprowadził do osłabienia rynku i sprawił, iż pozostał on w tyle za dynamicznie rozwijającym się przemysłem high-tech, a jego dalsze utrzymanie pogłębiłoby tylko zacofanie technologiczne i ograniczyło przepływ innowacji.

Po dojściu do władzy na początku lat 90. nowej fali polityków i technokratów diametralnie zmieniono politykę rozwoju gospodarczego, liberalizując stopniowo wymianę handlową i prywatyzując większą część państwowych firm. Polityka ta objęła także przemysł komputerowy, wyznaczając nowy etap w jego rozwoju, trwający od $1991 \mathrm{r}$. do chwili obecnej. Charakteryzuje się ona liberalizacją wymiany handlowej, prywatyzacją przedsiębiorstw państwowych działających w tym sektorze oraz ich przejmowaniem przez duże koncerny międzynarodowe. Silna konkurencja z nowocześniejszymi technologicznie wyrobami oferowanymi przez zagranicznych producentów doprowadziła do upadku bądź przejęcia większość brazylijskich firm działających w sektorze hardware. Zachowały się jedynie największe, najnowocześniejsze i najbardziej wszechstronne. Natomiast dynamiczny rozwój zaznaczył się w sektorze oprogramowania (software) i usług IT.

Wraz z liberalizacją polityki gospodarczej coraz aktywniej działają na rynku brazylijskim duże korporacje międzynarodowe, rozwijając działalność produkcyjną i badawczo-rozwojową. Pojawiające się nowe inwestycje sprawiły, iż w latach 1994-2006 zatrudnienie w przemyśle komputerowym wzrosło ponad 3,5-krotnie. Widoczne zmiany zaszły także w regionalnym rozmieszczeniu tego przemysłu. Stopniowo traci na znaczeniu stan São Paulo, w którym jeszcze w 1994 r. znajdowało się 50,6\% wszystkich zakładów i 62,0\% ogótu zatrudnionych, natomiast w 2006 już tylko odpowiednio 41,6\% i 43,3\%. Spektakularnym sukcesem może poszczycić się stan Amazonas, który w 2006 r. zajmował drugie miejsce pod względem wielkości zatrudnienia w przemyśle komputerowym, koncentrując 15,6\% ogółu zatrudnionych. Zlokalizowana w sąsiedztwie Manaus strefa wolnego handlu przyciągnęła licznych producentów sprzętu telekomunikacyjnego i komputerowego, stając się jednym z największych w kraju centrów produkujących wyroby high-tech.

Dynamiczny rozwój gospodarczy Brazylii oraz związane z nim przemiany pozwalają sądzić, iż w najbliższych latach sektor informatyczny będzie przeżywał gwałtowny wzrost produkcji i sprzedaży. Wiąże się to z jednej strony z polityką informatyzacji administracji centralnej i stanowej, rozwojem dostępu do komputerów i Internetu w szkołach oraz realizowaniem programów poprawiających dostępność do komputerów i Internetu najuboższym grupom społeczeństwa. Również wzrost zamożności brazylijskich gospodarstw domowych przy jednoczesnym relatywnym spadku cen sprzętu komputerowego pozwala na poszerzanie kręgu odbiorców i sprawia, iż brazylijski rynek komputerowy staje się jednym z bardziej liczących w skali świata.

\section{Literatura}

Adler E., 1986, Ideological ,guerrillas” and the quest for technological autonomy: Brazil's domestic computer industry, International Organization, vol. 40/3, s. 673-705.

Almeida M.C., 2005, The Evolution of the incubator movement in Brazil, International Journal of Technology and Globalisation, vol. 1/2, s. 258-277. 
Amann E., Baer W., 2002, The Development of Brazil's Technological Capabilities in the Post War Period: From Dependence to Self-Reliance, Latin American Business Review, vol. 3/1, s. 1-29.

Anuario Informatica Hoje 2008, 2008, Plano Editoral, São Paulo. http://www.anuarioih.com.br/anuih/ index.html

Dedrick J., Kraemer K.J., Palacios J., Tigre P.B., Botelho A.J.J., 2001, Economic Liberalization and the Computer Industry: Comparing Outcomes in Brazil and Mexico, World Development, vol. 29/7, s. 1199-1214.

Erber F.S., 1985, The Development of the „Electronics Complex” and Government Policies in Brazil, World Development, vol. 13/3, s. 293-309.

Evans P.B., 1986, State, Capital, and the Transformation of Dependence: The Brazilian Computer Case, World Development, vol. 14/7, s.791-808.

Evans P.B., 1989, Declining hegemony and assertive industrialization: U.S. - Brazil conflicts in the computer industry, International Organization, vol. 43/2, s. 207-238.

Etzkowitz H., Carvalho de Mello J.M., Almeida M., 2005, Towards „,meta-innovation” in Brazil: The evolution of the incubator and the emergence of a triple helix, Research Policy, vol. 34, s. 411-424.

Langer E.D., 1989, Generations of Scientists and Engineers: Origins of the Computer Industry in Brazil, Latin American Research Review, vol. 24/2, s. 95-111.

Pesquisa Industrial - Empresa, 2001-2006, Instituto Brasileiro de Geografia e Estatística - IBGE, Rio de Janeiro. http://www.ibge.gov.br/home/estatistica/economia/industria/pia/empresas/

Pesquisa Industrial - Produto, 2001-2006, Instituto Brasileiro de Geografia e Estatística - IBGE, Rio de Janeiro. http://www.ibge.gov.br/home/estatistica/economia/industria/pia/produtos/

Quandt C., 1997, The Emerging High-technology Cluster of Campinas, Brazil, International Develop-ment Research Center, Technopolis 97, September 9-12, Ottawa http://www.crdi.ca/cairo/ ev-23090-201-1-DO_TOPIC.html

Science, Technology \& Innovation Indicators in the State of Săo Paulo Brazil 2004, 2005, The State of São Paulo Research Foundation - FAPESP, São Paulo (http://www.fapesp.br)

Schoonmaker S., 1995, High-tech development politics: New Strategies and Persistent Structures in Brazilian Informatics, Sociological Quarterly, vol. 36/2, s. 369-395.

Tigre P.B., Botelho A.J.J., 2001, Brazil Meets the Global Challenge: IT Policy in a Postliberalization Environment, Information Society, vol. 17, s. 91-103.

\section{Processes of the development of the Brazil's computer industry}

The article examines development of the Brazilian industrial policy in the IT sector from the creation in 1959 a special agency concerned with computers - the Grupo Executivo para Aplicação de Copmputadores Electrônicos (GEACE) to the liberalization of the informatics policy introduced in 1991 and Computador para Todos program introduced in 2003. The IT policies prevailing in the 1970s and 1980s were oriented toward national production and development of technological capabilities. Since the 1991 protectionism was replaced by liberal policy with incentives and tax rebates as alternative mechanisms preserving some local equipment manufacturing and R\&D activities. The general economic success after the introduction in the 1994 Real Plan was also visible in the computer industry. During the years 1994-2006 the employment in this industry has more than tripled and the production of computers increased substantially.

dr Mirosław Wójtowicz

Uniwersytet Pedagogiczny im. Komisji Edukacji Narodowej w Krakowie

Instytut Geografii

Zakład Geografii Społeczno-Ekonomicznej

e-mail: mwojt@ap.krakow.pl 